Amsterdam Expeditions to the West Indian Islands, Report 31*

\title{
TUBIFICIDAE (OLIGOCHAETA) FROM SUBTERRANEAN WATERS, WITH DESCRIPTION OF TWO NEW GENERA
}

\author{
by \\ ELŻBIETA DUMNICKA \\ Laboratory of Water Biology, Polish Academy of Sciences, \\ 31-016 Kraków, Slawkowska 17, Poland
}

\begin{abstract}
SUMMARY
Two new genera of the family Tubificidae inhabiting springs, wells and interstitial waters of a brackish lake in the West Indies are described. These are Spirospermoides stocki gen. et sp. n. and Krenedrilus papillatus gen. et sp. n. A detailed description of the morphological characters and genital organs is provided. A comparison with allied genera and species is also made. The occurrence of some other species of this family has been recorded.
\end{abstract}

\section{RÉSUMÉ}

On donne la description de deux genres nouveaux de la famille des Tubificidae, vivant dans des sources, dans des puits et dans l'eau interstitielle d'un lac saumâtre des Indes Occidentales. Ce sont: Spirospermoides stocki gen. et sp. n. et Krenedrilus papillatus gen. et sp. n. Une description détaillée des particularités morphologiques et des organes génitaux est donnée. Une comparaison avec les espèces et les genres voisins a été également effectuée. La présence de quelques autres espèces de cette famille est aussi signalée.

\section{INTRODUCTION}

The oligochaete fauna of subterranean waters of the West Indian Islands and of northern South America has not been investigated so far. The material collected by the Amsterdam Expeditions to the West Indian Islands, which I received through the kindness of Prof. Dr. Jan H. Stock, is very extensive. It includes a few samples collected in the years 1973, 1975, 1976 and numerous samples from the years 1974 and 1978

* Report 30 is published in the same issue of this journal.
Tubificidae are very common in this material: out of 144 samples with oligochaetes, this family is present in 66 samples. Tubificidae occur in almost all habitats investigated, both natural and artificial. Natural habitats include: springs, karst sources, sinkholes, pools and lakes in caves, and fresh, brackish and marine interstitial waters. Artificial habitats include wells and cisterns.

Most of the specimens are immature, so it is impossible to determine the majority of the species. The specimens are preserved in the collections of the Zoölogisch Museum, Amsterdam (ZMA) and the Polish Academy of Sciences, Kraków (PAS).

\section{DESCRIPTION OF THE NEW TAXA}

\section{Spirospermoides gen. $\mathbf{n}$.}

Diagnosis. - Cutaneous cover thin and wrinkly with circles of small papillae. Hair and pectinate setae in dorsal bundles, only bifid setae in ventral bundles, ventral setae not modified on segment $\mathrm{X}$ and absent on segment XI.

Vas deferens long, coiled, not enlarged ectally, with the inner wall ciliated entally, entering atrium apically. Atrium small, crescent-shaped, with inner wall non-ciliated. Prostate gland opening almost apically into the atrium. Ductus ejaculatorius absent. Penis with thick cuticular penis sheath. Spermatheca large, with ovoid ampulla, ectal duct long, coiled. Spermatozeugmata clavate, moderately long. 
The new genus is related to the genus Spirosperma Eisen, 1879 (see Holmquist, 1978). Differences between these two genera are shown in table I.

Type-species of the genus. - Spirospermoides stocki $\mathrm{sp} . \mathrm{n}$.

Etymology. - Spirospermoides means similar to Spirosperma.

\section{Spirospermoides stocki sp. $\mathrm{n}$.}

(Figs. 1-3)

Material.- Holotype: mature specimen, whole mount, and 3 paratypes, Amsterdam Expeditions to the West Indian Islands, sta. 78/243, Haiti, Dépt. de l'Ouest, Source du Trou Caiman $\left(18^{\circ} 39^{\prime} 22^{\prime \prime} \mathrm{N} 72^{\circ} 08^{\prime} 23^{\prime \prime} \mathrm{W}\right)$, just S. of the road; large, fast-running karst spring; bottom with gravel, roots, leaves; chlorinity $320 \mathrm{mg} / \mathrm{l} ; 10$ May 1978. Holotype (ZMA), 3 paratypes (ZMA).

Sta. 78/226: Haiti, Dépt. de l'Ouest, Etang Saumâtre, E.S.E. of village of Fond Parisien $\left(18^{\circ} 29^{\prime} 19^{\prime \prime} \mathrm{N} 71^{\circ}\right.$ $56^{\prime} 25^{\prime \prime} \mathrm{W}$ ), in interstitia of coarse sand on the shore of the lake, just above the waterline near a freshwater pool; chlorinity $110 \mathrm{mg} / \mathrm{l} ; 7$ May 1978 . Four mature specimens (paratypes) (PAS).

Sta. 78/279: Curaçao, springs of the hamlet of San Pedro $\left(12^{\circ} 15^{\prime} 32^{\prime \prime} \mathrm{N} 69^{\circ} 02^{\prime} 36^{\prime \prime} \mathrm{W}\right)$; natural spring, slowly running; bottom of sand; chlorinity $1000 \mathrm{mg} / \mathrm{l} ; 14$ May 1978. Four mature specimens (ZMA).

Description.- Length of preserved specimens: 9-13 mm. Number of segments: 54-98. Cutaneous cover thin and wrinkly, small papillae in 2 circles per segment.

Dorsal anterior bundles with 1-2 hair setae 170-250 $\mu \mathrm{m}$ long and 2-3 pectinate setae 60-75 $\mu \mathrm{m}$ long, with 2 or 3 thin intermediate teeth (fig. 1A). Dorsal postclitellar bundles with 1 hair seta longer than in the preclitellar segments (340-450 $\mu \mathrm{m})$ and 2 pectinate setae $50-75 \mu \mathrm{m}$ long. In the terminal segments hair setae short (about $120 \mu \mathrm{m}$ ) or absent. Ventral anterior bundles with 4-6 bifid setae with distal tooth longer than proximal and distal nodulus (fig. 1B). Ventral postclitellar setae 3-4 per bundle, with equal teeth (fig. 1C). Spermathecal setae unmodified, penial setae absent.

Clitellum on XI-1/2 XII segments. Vas deferens very long, coiled, sometimes extending

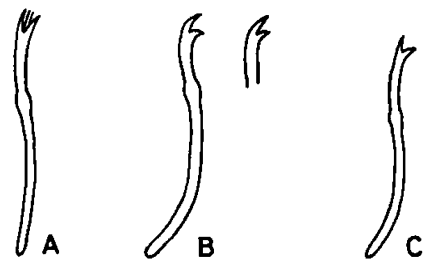

Fig. 1. Spirospermoides stocki sp. n.: A, dorsal pectinate seta of preclitellar segment; B, ventral setae of preclitellar segment; $C$, ventral seta of postclitellar segment.

backward to the 12th segment, with ental part ciliated. Width of ciliated and non-ciliated parts almost the same. Vas deferens entering atrium apically. Atrium small, crescent-shaped, slightly narrowed ectally and entally, with inner wall non-ciliated (fig. 2). Prostate gland mediumsized, opening almost apically into the atrium. Penis large, bend with thick cuticular sheath

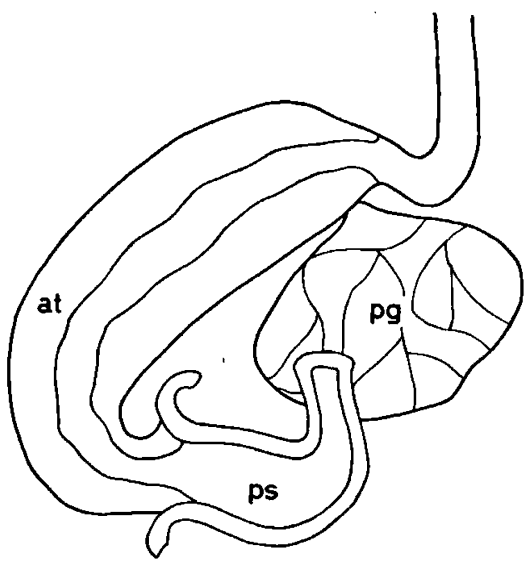

Fig. 2. Spirospermoides stocki sp. n., male duct of holotype (at = atrium; pg = prostate gland; ps = penis sheath).

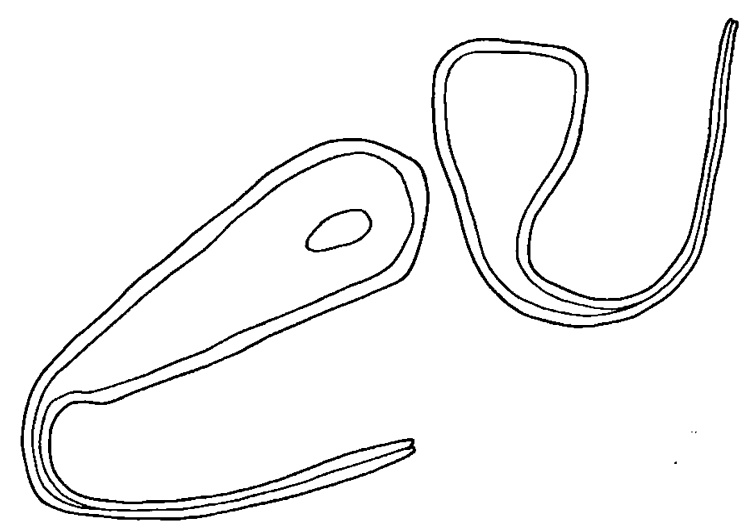

Fig. 3. Spirospermoides stocki sp. n., spermatozeugmata. 
(fig. 2). Spermatheca large, ampulla ovoid, reaching segment XI (when filled with spermatozeugmata), ectal duct long, coiled. Spermatozeugmata not very long, clavate (fig. 3).

Discussion.- This new species is easily distinguished from all species of the related genus Spirosperma Eisen, 1896, viz. from $S$. ferox Eisen, 1896 (see Holmquist, 1978), $S$. apapillatus (Lastochkin \& Sokolskaya, 1953) and $S$. tenuis (Hrabe, 1931), by its anatomical characters (see table I) and shape and number of setae. The general characteristics of the species Peloscolex superiorensis Brinkhurst \& Cook, 1966, and $P$. nerthoides Brinkhurst, 1965 (sensu Brinkhurst in Brinkhurst \& Jamieson, 1971) are similar to those of Spirospermoides stocki sp. n., but the shape of the cuticular penis sheath permits to distinguish these species. Spirospermoides stocki sp. $\mathbf{n}$. has a large and bent penis sheath, whereas $P$. superiorensis has a long, cylindrical one, and $P$. nerthoides has an elongate, thimbleshaped penis sheath. Moreover, in these two species of Peloscolex sensu Brinkhurst (in Brinkhurst \& Jamieson, 1971), papillae are absent.

TABLE I

Differences between the genera Spirosperma Eisen and Spirospermoides gen. $\mathbf{n}$.

\begin{tabular}{|c|c|c|}
\hline & Spirosperma Eisen & Spirospermoides gen. $\mathbf{n}$. \\
\hline Vas deferens & non-ciliated entally & ciliated entally \\
\hline $\begin{array}{l}\text { Inner wall of } \\
\text { atrium }\end{array}$ & ciliated & non-ciliated \\
\hline Prostate gland & $\begin{array}{l}\text { opening to the atrium above } \\
\text { the middle of concave side }\end{array}$ & $\begin{array}{l}\text { opening to the atrium } \\
\text { almost apically }\end{array}$ \\
\hline $\begin{array}{l}\text { Ductus } \\
\text { ejaculatorius }\end{array}$ & long, winding & absent \\
\hline Spermatozeugmata & long, narrow & moderately short, clavate \\
\hline
\end{tabular}

Habitat data. - Spirospermoides stocki sp. n. occurs in various habitats and substrates with a sandy and gravelly bottom of springs and lacustrine interstitia. It shows high resistance to chlorinity: from $110 \mathrm{mg} / \mathrm{l}$ to $1000 \mathrm{mg} / \mathrm{l}$. Associated oligochaete fauna: sta. 78/243 Stephensoniana trivandrana (Aiyer, 1926), Tubificidae gen. spp. juv., and Enchytraeidae gen. spp. juv.; sta. 78/226 Pristina synclites Stephenson, 1925, and Tubificidae gen. spp. juv.; sta. 78/279 Propappus glandulosus Michaelsen, 1905, Achaeta sp. juv., and Tubificidae gen. spp. juv.

\section{Krenedrilus gen. $\mathbf{n}$.}

Diagnosis. - Body wall densely covered with small papillae. Hair and pectinate setae in dor- sal bundles. Bifid and simple pointed setae in ventral bundles. Spermathecal setae nonmodified, penial setae modified. Vas deferens moderately long, entering atrium apically. Atrium tubular with high, non-ciliated inner wall. Prostate gland medium-sized, entering atrium subapically. Penis in penial pouch, without cuticular sheath. Spermatheca large, ovoid, ectal duct long. Spermatozeugmata long and narrow.

Type-species of the genus. - Krenedrilus papillatus sp. $\mathrm{n}$.

Etymology. - The proposed name of the genus is composed of the Greek words: $\varkappa \varrho \eta \nu \eta$ (= spring) and $\delta \varrho i \lambda o s$ (= worm). The specific Latin name, papillatus, means covered with papillae. 
Krenedrilus papillatus sp. $\mathrm{n}$.

(Figs. 4-7)

Material. - Holotype (mature specimen) and 3 paratypes, also mature specimens with posterior end missing, whole mount (ZMA). Amsterdam Expeditions to the West Indian Islands, sta. 78/316: Venezuela, Distrito Falcón (Paraguana peninsula), Fuente de Miraca (estimated position $11^{\circ} 52^{\prime} 56^{\prime \prime} \mathrm{N} 69^{\circ} 51^{\prime} 32^{\prime \prime} \mathrm{W}$ ); slowly running, natural spring, discharging in a pool; bottom sandy, with roots; chlorinity $910 \mathrm{mg} / \mathrm{l} ; 25$ May 1978.

Description. - Small species, about $7 \mathrm{~mm}$ long. Body wall densely but finely papillated (fig. 4).

Hair setae 2-3 per bundle anteriorly and 1-2 posteriorly. Length of hair setae increases on the preclitellar segments and it amounts to 140-200 $\mu \mathrm{m}$ on segment III, 200-290 $\mu \mathrm{m}$ on segment $V$ and $370-420 \mu \mathrm{m}$ on segment VII. In the postclitellar segments the length of hair setae decreases to 200-250 $\mu \mathrm{m}$. Dorsal crotchets pectinate (fig. 5A), 2-3 per bundle, 37-50 $\mu \mathrm{m}$ long, with long lateral teeth and 2 intermediate teeth, difficult to observe (immersion is needed). Ventral anterior bundles with 4-6 setae, both bifid and single-pointed, 35-45 $\mu \mathrm{m}$ long (fig. 5B). Posterior bundles with 3-4 bifid setae, 37-45 $\mu \mathrm{m}$ long with distal teeth a little shorter than the proximal ones. Sometimes 1 single-pointed seta also present. Segment X with ventral setae nonmodified. Segment XI with bundles of modified penial setae, consisting of 5-7 straight setae $62-70 \mu \mathrm{m}$ long (fig. 5C).

There is a sudden stomach dilatation in segment VII or VIII.

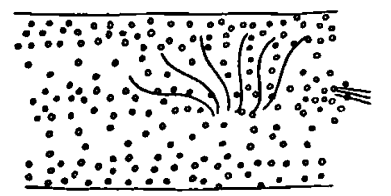

Fig. 4. Krenedrilus papillatus sp. n., body wall with papillae.

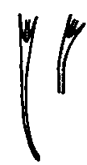

A

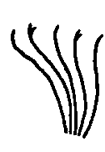

B

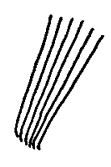

C
Fig. 5. Krenedrilus papillatus sp. n.: A, dorsal pectinate setae of preclitellar segment; $B$, bundle of ventral setae; $C$, bundle of penial setae.

Clitellum on segment XI. Vas deferens moderately long, with inner wall non-ciliated, entering apically into the atrium (fig. 6A, B). Atrium tubular, with high non-ciliated cells on the inner wall. Penis small, without cuticular sheath in penial pouch. Prostate gland mediumsized, entering atrium near the ental end. Spermatheca large, the shape of the ampulla varies a little: normally ovoid, sometimes slightly narrowed in the middle part (fig. 7). Ectal duct long. Ampulla filled with long and narrow spermatozeugmata.

Discussion. - The genital organs of Krenedrilus papillatus sp. n. are similar to those of the genus Haber Holmquist, 1978, and some

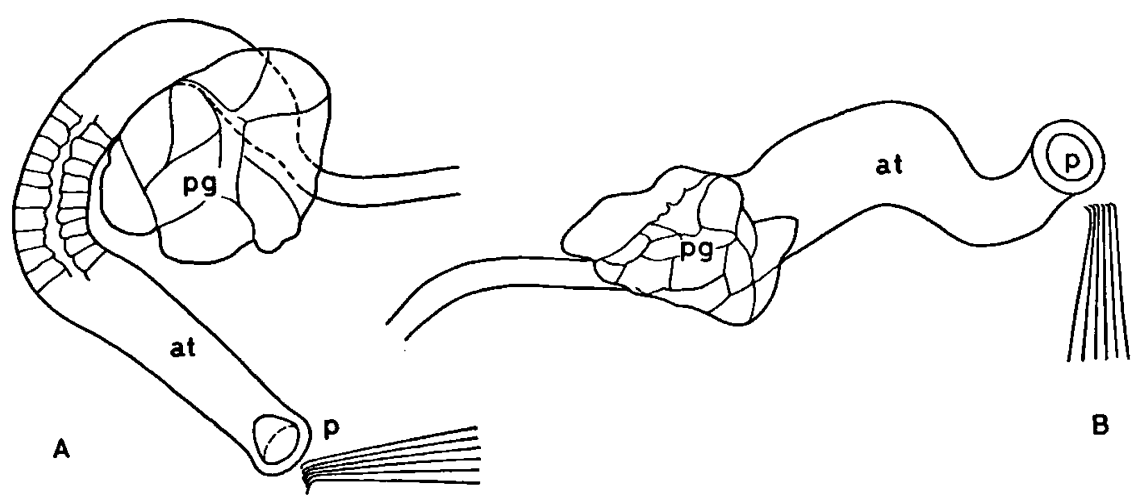

Fig. 6. Krenedrilus papillatus sp. n.: A, male duct of holotype; B, male duct of paratype (at = atrium; pg = prostate gland $\mathrm{P}=$ penis). 

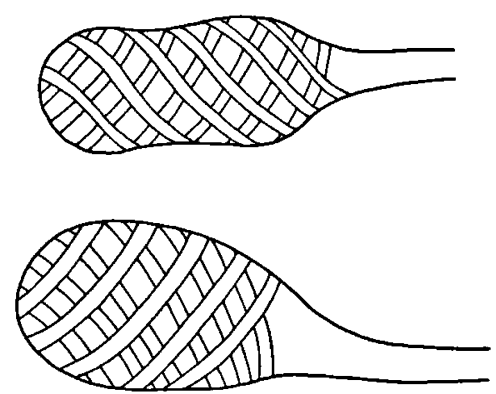

Fig. 7. Krenedrilus papillatus sp. n., spermathecae filled with spermatozeugmata.

species of the genus Isochaeta Pointner, 1911, but they differ in some important characters (table II). Unfortunately, the description of the genital organs of Isochaeta species is incomplete, which renders a comparison difficult. Moreover, the setal formulae of the genera discussed here are quite different (table II). The shape and number of the penial setae of Krenedrilus gen. n. is unusual for the subfamily
Tubificinae, while this type of penial setae occurs in Phallodrilinae.

\section{NOTES ON OTHER TUBIFICIDAE}

\section{Limnodrilus udekemianus Claparède, 1862}

Material. - Amsterdam Expeditions to the West Indian Islands, sta. 78/31: Barbuda, Spring Well (near airstrip) $\left(17^{\circ} 38^{\prime} 03^{\prime \prime} \mathrm{N} 61^{\circ} 49^{\prime} 19^{\prime \prime} \mathrm{W}\right)$; an open well with fairly clean water; chlorinity $1280 \mathrm{mg} / \mathrm{l} ; 10$ April 1978 . One specimen (ZMA).

Sta. 78/174: Vieques, well in the village of Monte Santo (estimated position $18^{\circ} 07^{\prime} 51^{\prime \prime} \mathrm{N} 65^{\circ} 27^{\prime} 18^{\prime \prime} \mathrm{W}$ ); well in hut in a small valley; 1 May 1978. Five specimens (ZMA).

Sta. 78/209: Haiti, Dépt. de l'Ouest, spring on the new road from Léogâne to Jacmel, just $\mathrm{N}$. of the boundary between the départements de l'Ouest and du Sud-Est (estimated position $18^{\circ} 21^{\prime} 59^{\prime \prime} \mathrm{N} 72^{\circ} 35^{\prime} 45^{\prime \prime} \mathrm{W}$ ); clear, natural spring with muddy bottom; chlorinity $40 \mathrm{mg} / 1 ; 5$ May 1978. Three specimens (PAS).

Sta. 78/218: Haiti, Dépt. du Centre, small springs E. of the hamlet of Trianon (= S. of Mirebalais) (estimated position $18^{\circ} 47^{\prime} 31^{\prime \prime} \mathrm{N} 72^{\circ} 06^{\prime} 41^{\prime \prime} \mathrm{W}$ ); natural springs in the

TABLE II

Differences between Krenedrilus gen. n. and the genera Haber Holmquist, 1978, and Isochaeta Pointner, 1911.

\begin{tabular}{|c|c|c|c|c|c|}
\hline & Krenedrilus & Haber & $\begin{array}{l}\text { Isochaeta israelis } \\
\text { Brinkhurst, } 1971\end{array}$ & $\begin{array}{l}\text { Isochaeta nevadana } \\
\text { Brinkhurst, } 1965\end{array}$ & other Isochaeta \\
\hline $\begin{array}{l}\text { Hair and } \\
\text { pectinate setae }\end{array}$ & present & present & present & present & absent \\
\hline $\begin{array}{l}\text { Simple-pointed } \\
\text { setae in ventral } \\
\text { bundles }\end{array}$ & present & absent & absent & absent & absent \\
\hline $\begin{array}{l}\text { Spermathecal } \\
\text { setae }\end{array}$ & unmodified & modified & unmodified & unmodified & $\begin{array}{l}\text { in some cases } \\
\text { modified }\end{array}$ \\
\hline Penial setae & modified & modified & unmodified & unmodified & $\begin{array}{l}\text { in some cases } \\
\text { modified }\end{array}$ \\
\hline Vas deferens & $\begin{array}{l}\text { long, not enlarged } \\
\text { ectally }\end{array}$ & $\begin{array}{l}\text { long, enlarged } \\
\text { ectally }\end{array}$ & long & short & long \\
\hline Prostate gland & medium size & medium size & small & small & small \\
\hline $\begin{array}{l}\text { Ductus } \\
\text { ejaculatorius }\end{array}$ & absent & present & ? & ? & ? \\
\hline $\begin{array}{l}\text { Cuticular penis } \\
\text { sheath }\end{array}$ & absent & absent & present & present & $\begin{array}{c}\text { in some cases } \\
\text { present }\end{array}$ \\
\hline
\end{tabular}


bank of a brook; slowly running; bottom loam and sand; chlorinity $90 \mathrm{mg} / \mathrm{l} ; 6$ May 1978. One specimen (PAS).

L. udekemianus was found in two springs and two wells with sandy or muddy bottom, at chlorinities ranging from $40-90 \mathrm{mg} / \mathrm{l}$ to 1280 $\mathrm{mg} / \mathrm{l}$. This is a cosmopolitan species, occurring in various water bodies (including polluted waters), but up to now it was never recorded at such high chlorinities. Almost all specimens are mature: the shape and size of the genital organs are typical of this species.

Embolocephalus velutinus (Grube, 1879) (Figs. 8-9)

Material. - Amsterdam Expeditions to the West Indian Islands, sta. 78/172: Vieques, village of Monte Santo, open well behind a house $\left(18^{\circ} 07^{\prime} 34^{\prime \prime} \mathrm{N} 65^{\circ} 26^{\prime} 55^{\prime \prime} \mathrm{W}\right)$; 1 May 1978. Three specimens (ZMA).

Sta. 78/317: Venezuela, Distrito Falcón (Paraguana peninsula), windpump on well in the village of Miraca (estimated position (11 $\left.52^{\prime} 54^{\prime \prime} \mathrm{N} 69^{\circ} 51^{\prime} 34^{\prime \prime} \mathrm{W}\right)$; chlorinity $1090 \mathrm{mg} / \mathrm{l} ; 25$ May 1978 . Two specimens (PAS).

Up to now $E$. velutinus was known from Europe only, where it occurs mainly in subterranean waters, but also in springs, mountain streams and deep lakes with muddy bottom.

Length of preserved specimens: $10-14 \mathrm{~mm}$. Number of segments: 40-45. Body wall densely papillated.

Dorsal bundles consist of only 1 hair seta and 1 or rarely 2 very fine hair-like crotchets. Each ventral bundle consists of 1 single-pointed and 1 bifid seta with reduced distal tooth. The proximal end of the setae are placed in the setal sac (fig. 8). Spermathecal setae modified, penial setae absent. Vas deferens long, coiled, atrium cylindrical, penis without cuticular penis sheath. Spermatheca with very long ampulla, indistinctly set off from the short ectal duct (fig. 9).

Some characters of the specimens examined are different from the previous descriptions. The length of the body, the number of segments and the number of setae in the dorsal bundles are smaller than usual (Brinkhurst, in Brinkhurst \& Jamieson, 1971; Kasprzak, 1981).

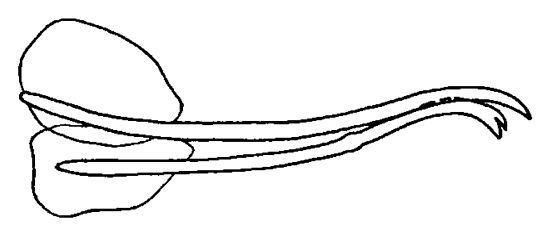

Fig. 8. Embolocephalus velutinus (Grube, 1879), bundle of ventral setae.

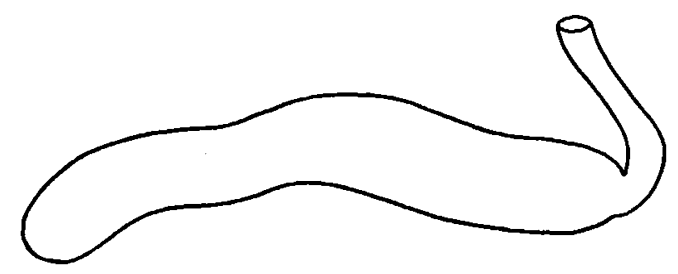

Fig. 9. Embolocephalus velutinus (Grube, 1879), spermatheca.

The ampullae of the spermathecae are very long and the ectal ducts are short, whereas the typical specimens have slighty elongated ampullae and quite long ectal ducts.

The decrease in body size may be caused by unfavourable life conditions, but the reasons for the overgrowth of ampullae are difficult to explain. Probably the accumulation of big masses of spermatozeugmata is profitable to these animals.

\section{ACKNOWLEDGEMENTS}

I am grateful to Prof. Dr. Jan H. Stock, who kindly entrusted me the study of the oligochaetes and who provided a detailed description of the stations.

The materials were collected during the Amsterdam Expeditions to the West Indian Islands (leader: Prof. Dr. J. H. Stock), financed by the Netherlands Foundation for the Advancement of Tropical Research (WOTRO), The Hague; the Treub Maatschappij, Utrecht; and the Beijerinck-Popping Fonds, Amsterdam.

\section{REFERENCES}

BrinkhURst, R. O. \& B. G. M. Jamieson, 1971. Aquatic Oligochaeta of the world: i-xiv, 1-860 (Oliver Boyd, Edinburgh).

ERSÉUS, Ch., 1980. Specific and generic criteria in marine Oligochaeta, with special emphasis on Tubificidae. In: R. O. Brinkhurst \& D. G. Cook eds., Aquatic oligochaete biology: 9-24 (Plenum Publishing Corporation, New York). 
Holmquist, Ch., 1978. Revision of the genus Peloscolex (Oligochaeta, Tubificidae). 1. Morphological and anatomical scrutinity; with discussion on the generic level. Zoologica Scr., 7 (3): 187-208.

Hrabev, S., 1931. Die Oligochaeten aus den Seen Ochrida und Prespa. Zool. Jb., (Syst.) 61 (1/2): 1-62, pl. 1.

KasprzaK, K., 1981. Skaposzczety wodne, I. Rodziny: Aeolosomatidae, Potamodrilidae, Naididae, Tubi- ficidae, Dorydrilidae, Lumbriculidae, Haplotaxidae, Glossoscolecidae, Branchiobdellidae. Klucze do oznaczania bezkręgowców Polski, 4: 1-226 (Państwowe Wydawnictwo Naukowe, Warszawa).

Lastochkin, D. A. \& N. L. Sokolskaya, 1953. New oligochaete species of the genus Peloscolex (fam. Tubificidae) from the Amur basin. Zool. Zh., 32: 409-412. [In Russian.]

Final draft received: 11 February 1983 